\title{
Alternative Dispute Resolution vs. Judicial Conciliation in the Civil Process of Transit States: A Comparative Study
}

\author{
Oleksandr B. Tykhanskyi ${ }^{1,}$, Oksana Z. Khotynska-Nor ${ }^{2}$, Nataliia V. Vasylyna $^{3}$ and \\ Maria V. Bondarieva ${ }^{2}$
}

${ }^{1}$ Department of the Jurisdiction Forms of Legal Protection of Subjects of Private Law, the Judiciary and Legal Proceedings, Academician F.H. Burchak Scientific and Research Institute of Private Law and Entrepreneurship of the National Academy of Legal Sciences of Ukraine, Kyiv, Ukraine

${ }^{2}$ Department of Notary, Enforcement Procedure and Advocacy, Prosecution, Litigation, Taras Shevchenko National University of Kyiv, Kyiv, Ukraine

${ }^{3}$ Department of Civil Procedure, Taras Shevchenko National University of Kyiv, Kyiv, Ukraine

\begin{abstract}
The study investigates the current problems of judicial and extra-judicial conciliation procedures (alternative ways of resolving civil disputes) in states that have just started implementing such a procedural tool. Despite the fact that the term "conciliation procedures" is actively used in the science of civil procedure, this category is rather vague in countries that are just beginning to apply judicial conciliation in parallel with other conciliation procedures. Priority attention is focused on practical, legislative, and scientific problems of applying this procedural tool for rapid resolution of legal conflicts in Ukraine, as a state that only in 2017 (and in fact since the beginning of 2018) introduced this legal innovation. The purpose of the study is to elaborate on the legal nature and correlation between judicial conciliation (settlement of civil disputes with the participation of a judge under Ukrainian legislation) and alternative ways of resolving civil disputes. The study is based on several scientific methods that have identified the logic and general direction of knowledge of the problem of judicial conciliation. In particular, to determine the legal nature, essence, criteria of correlation, and delimitation of alternative dispute resolution and judicial conciliation, the study used the dialectical scientific cognition method. The study engages in a comparative study of the statutory regulation of similar procedures in the Russian Federation and Belarus legislation. It is concluded that alternative dispute resolution and judicial conciliation are closely interrelated and, depending on their types, can sometimes manifest themselves as synonymous categories or institutions of law.
\end{abstract}

Keywords: Mediation, negotiations, arbitration, commercial arbitration, civil dispute.

\section{INTRODUCTION}

Conceptual reforms of justice in 2016 at the constitutional level were aimed at creating justice of the European type in Ukraine as a democratic state. Such changes have been sought by Ukrainian society since Ukraine's independence, especially in 2013-2014. At the constitutional level, significant changes have been introduced in the judicial system and new administration principles of justice at the institutional level. Within this study's framework, only one but key constitutional innovation is singled out, which indirectly concerns judicial conciliation. Thus, the fundamental constitutional provision covering justice is Article 124 of the Constitution of Ukraine, Part 3 of which states as follows: "The law may determine the mandatory pretrial procedure for dispute resolution" (Constitution of Ukraine, 1996). Consolidation of this provision at the constitutional level aimed to create specific conditions for resolving conflicts between persons without going to court. In the doctrine, such an approach is defined as

*Address correspondence to this author at the Academician F.H. Burchak Scientific and Research Institute of Private Law and Entrepreneurship of the National Academy of Legal Sciences of Ukraine, Kyiv, Ukraine;

Tel: (044) 286-70-98, E-mail: tykhanskyi6@ust-hk.com.cn the resolution of legal conflicts from the standpoint of interests. This method is based on clarifying and taking into account the parties' mutual interests and aims to reach a mutually beneficial agreement, as a result of which no party to the conflict loses.

The practice of using alternative methods of dispute resolution, which are an alternative to official justice in the judicial system of the state, has developed in the world. In Western legal doctrine, such methods are called alternative dispute resolution (Frye, 2019). The result of the alternative process is the awareness of each party of the resolved legal conflict of the fairness of the decision, which will gradually but significantly affect the development of a culture of harmony in society, in contrast to the culture of claims, complaints, and accusations (Romanadze, 2017). It is emphasised that a side effect and no less desirable consequence for the judicial system of Ukraine is the load relief for courts. Such a positive side effect for the judiciary is sought by all states in periods of transformation to democracy (Chan, 2017; Arkhipkina et al., 2020). The effectiveness of judicial mediation creates the foundations for the introduction of the idea of "justice of compromise and social peace" at the constitutional 
level (Zdrok, 2013), where the task of reconciling the parties comes first, as opposed to the resolution of the dispute. In case of failure to reconcile, the Constitution of Ukraine enshrines the extension of the jurisdiction of the courts to any dispute and any criminal charge.

Thus, the right to judicial protection is not lost, but on the contrary, is optimised in time and property frameworks through the introduction of alternative dispute resolution. The literal content of this constitutional norm refers to the need to legislate various procedures of mandatory pre-trial dispute resolution, the most common of which and familiar to society is, admittedly, mediation. At the same time, the latest legislative changes in Ukraine (as of the end of 2020) after the judicial-constitutional reform of 2016 indicate that the legislator is in no hurry to adopt a special law that would regulate the principles, approaches, and procedure of mediation in Ukraine, despite many versions of draft laws registered in the Verkhovna Rada (Draft Law "On mediation", 2010, 2011, 2012, 2013, 2015, 2020; UNCITRAL Arbitration Rules, 1976; UNCITRAL model law..., 1985). At the same time, systemic changes to procedural legislation, namely the wording of Ukraine's procedural codes (civil, administrative, and commercial litigation), enshrined the possibility of exercising a person's right to settle a dispute other than litigation after filing a lawsuit and within civil proceedings. This method is the legislative consolidation of the innovation of civil procedural law in Chapter 4 Section III of the Civil Procedural Code of Ukraine - "Settlement of a dispute with the participation of a judge" (Law of Ukraine..., 2017). This new institution of civil procedural law is designed to maximally assist the parties to promptly resolve a civil dispute that has arisen between them, not on the basis of law but within the law. Therewith, other alternative ways of resolving a legal conflict (dispute) in a legal (including civil) procedure aim to achieve this goal: mediation, the institution of agreements in civil proceedings, arbitration, international commercial arbitration, negotiations, mediation, etc.

\section{LITERATURE REVIEW}

General characteristics of alternative dispute resolution as conciliation procedures in civil procedural legislation. The term "conciliation procedures" is actively used in the science of civil procedure while remaining rather vague (Arkhipkina et al., 2020). Analysing the views of modern scholars on this concept, it should be noted that conciliation procedures are usually considered as a kind of alternative ways of resolving legal conflicts, i.e., social means that constitute an alternative to the judicial method of dispute resolution, which dominates the current stage of society (Kalashnykova, 2011; Zdrok, 2013). UNCITRAL, as a subsidiary body of the UN General Assembly, established in 1966 to promote international trade law, describes the conciliation procedure as a process in which an individual or group of persons is invited by the parties to assist them independently and impartially in achieving a peaceful dispute resolution (UNCITRAL Arbitration Rules, 1976).

There is also an opinion that alternative dispute resolution constitutes a set of different procedures that aim to overcome legal conflict (Zadorozhna, 2012). They are performed, as a rule, by a non-governmental body or an individual, based on the principles of voluntariness, neutrality, confidentiality, dispositive, equality (Frye, 2019). The concept of alternative dispute resolution includes: conciliation, mediation; arbitration of disputes; both the arbitration method of resolving disputes, and the conciliation procedure (Zadorozhna, 2012). O.V. Goretsky (2016), analysing foreign experience in the legal regulation of conciliation proceedings in civil proceedings with reference to other scholars, notes that since the late 1990s, the idea of alternative dispute resolution in general and mediation, in particular, has been actively disseminated and promoted in Europe, in order to take the necessary measures in the field of judicial cooperation in civil matters to ensure the proper functioning of the internal market (Galiakbarova and Saimova, 2016). Goretsky also notes that a certain result of development was the adoption in 2008 by the European Parliament and the Council of the EU Directive on certain aspects of mediation in civil and commercial matters (Goretsky, 2016). In addition, C. Szymanski and K. AntolakSzymanski, (2020), upon analysing the experience of mediation in legal dispute resolution in the United States, concluded that extra-judicial methods of dispute resolution are traditionally considered as an alternative, i.e., legal forms that exist in parallel with the system of state courts and recourse to which is considered as an alternative to instituting proceedings in court.

The Green Paper on Alternative Dispute Resolution in Civil and Commercial Law, prepared by the European Community Commission in Brussels on April 19, 2002, states that the Commission understands alternative dispute resolution methods as more conciliatory than recourse to court and arbitration (Kosovsky, 2016). Alternative methods for the 
purposes of the Green Paper are defined as an out-ofcourt dispute resolution process engaged in by a neutral third party, excluding arbitration. In this case, apart from arbitration, the concept of alternative dispute resolution does not include: expert opinions, which do not constitute a method of dispute resolution, although provided within, for example, court or arbitration with a third party (an expert); procedures regarding the protection of consumer rights that occur without the involvement of a third party; the so-called "automated negotiation system" that does not require human resources but is offered by IT service providers (such systems not constitute a third-party dispute resolution, being a technical tool designed to facilitate direct negotiations between the parties to the dispute). The exclusion of arbitration from alternative dispute resolution methods is explained by the fact that, according to the Commission, arbitration is closer to quasi-judicial procedures than to alternative ones, in particular, because arbitration makes a decision that replaces a court decision (Zadorozhna, 2012). Belarusian researcher O.N. Zdrok (2013) subjects the conclusion of C. Szymanski and K. Antolak-Szymanski (2020) to temporal analysis and emphasises that this definition has changed significantly over time, given the procedures that exist not only in parallel with the judiciary and judicial protection but also within the judiciary as an alternative to a full-scale trial. Similar positions are available in foreign scientific and international sources (Thomas and Tomlinson, 2017; Moltmann-Willisch, 2014; European Commission..., 2019).

Joining the above approaches to the definition of "conciliation procedures", the authors of this study state that such procedures can successfully exist today both outside the court procedure, parallel with it, and within the court consideration of a civil dispute. The institution of civil dispute settlement with the participation of a judge is currently the most statutorily detailed in the civil procedural legislation of Ukraine. This study will elaborate on the general characteristics of conciliation procedures as a specific phenomenon in civil proceedings. Firstly, they possess a common feature: all processes that take place within the various conciliation procedures end with a single written agreement. In some cases, such an agreement is a final document; in others, the agreement requires confirmation by an authorised body - the court by issuing a decision. The key principle of conciliation procedures is the existence of a conflict of the parties, the resolution or settlement of which is possible through a clearly defined list of strategies of the parties in it, namely: compromise, cooperation, an adjustment in the form of unilateral concessions. Thus, in accordance with Part 2 of Article 2 of the Civil Procedural Code of Ukraine, the task of civil proceedings is a fair, impartial, and timely consideration and resolution of civil cases in order to effectively protect violated, unrecognised, or disputed rights, freedoms or interests of individuals, rights, and interests of legal entities, state interests (Law of Ukraine..., 2017). General courts hear civil disputes, the share of which concerns violated, unrecognised, or disputed civil rights. The fundamental principle of civil law is the principle of restoration of the situation that existed prior to the violation, if possible, and the principle of full compensation. Therefore, when going to court, a person seeks to restore justice through a court ruling that this person will consider fair.

However, a trial due to clear procedural procedures may not always fully restore the infringed right. The reasons for this can be different: poor-quality statements on the merits (statement of claim, recall, objection, etc.), statements on procedural issues that also affect the course of the trial, legislative conflicts and gaps, etc. However, recent amendments to the Constitution of Ukraine on justice and the adoption of the Law "On the Judiciary and the Status of Judges" No. 1402-VIII of June 22016 (Law of Ukraine..., 2016) established the rule of law as a starting point for the administration of justice by courts. Also, the Civil Procedural Code of Ukraine has legislatively consolidated the possibility of a court, in case the law or contract does not determine an effective way to protect the violated, unrecognised or disputed right, freedom, or interest of the person who appealed to the court, to determine in its decision a method of protection that does not contradict the law (Part 2 of Article 5). That is, theoretically, the courts of Ukraine currently have all the necessary arsenal of procedural and legal mechanisms for rendering a lawful and reasonable decision and can fairly resolve a civil dispute without crossing the line of the stated requirements.

Unfortunately, the small practice of applying these conceptual innovations does not yet provide a complete picture for an affirmative conclusion on such expectations. The significant need for judicial staff, significant workload and constant unsystematic changes to the current legislation create many risks for the objective impossibility of an in-depth, comprehensive, and exhaustive consideration of each 
civil case within a reasonable time. As a rule, the consequences of this situation are the desire of the parties to speed up the trial in various ways, including by filing complaints about the judge's actions to the judicial authorities, the High Council of Justice, including dissatisfaction with the parties to the trial. This situation affects the unwillingness of the party to recognise the court decision as fair, and it is natural that a considerable number of people in the future turn to the appellate review of the case. Therefore, the application of conciliation procedures in civil proceedings should be considered as a manifestation of the disposition principle, according to which each party to the dispute should have the right to choose options for resolving the conflict and use the arsenal of legal and customary options: a full-scale judicial protection procedure in a general or simplified manner (depending on the circumstances of the case); arbitration of the dispute (if the law allows transferring the dispute to arbitration); negotiations (claims) and conciliation procedures prior to recourse to the court; mediation; pre-trial settlement of a dispute with the participation of a judge, amicable settlement in civil proceedings, etc. It is the availability of a considerable number of tools that allows the creation of several conditional "doors" that lead to the restoration of justice and allow the parties to choose the procedure that would best suit their interests in terms of cost, efficiency, level of trust and predictability. Also, within the conciliation procedures, other strategies are singled out, in particular rivalry (competition) - a forceful style aimed at establishing one's position on the "win-loss" principle, as well as avoidance - conscious withdrawal of the party from interaction and confrontation (Zdrok, 2013).

Each party chooses its strategy(-ies) to overcome the conflict, which is achieved by resolving a certain factual existing, but not stated, or stated substantive demand in the statement of claim submitted to the general court. The search for the most appropriate options for resolving the substantive component of the conflict is the essence of conciliation procedures. In terms of the substantive nature of the conflict, T.V. Sakhnova (2012) emphasises that conciliation procedures are allowed if their subject is a coordination relationship of a dispositive type, i.e., those that, in principle, according to their substantive nature, allow self-regulation by the free will of the parties. Concluding the study of strategies within conciliation procedures, the Belarusian scientist creates a useful definition of conciliation procedures for the science of civil procedural law of Ukraine. The conciliation procedure, according to O.N. Zdrok (2013), is a specially organised (including within the framework of a jurisdictional body) interaction of conflicting parties of varying degrees of formality, aimed at encouraging them to change their strategy of behaviour in a conflict from rivalry (withdrawal) to cooperation (compromise, adaptation) with agreement on this the basis of the parties' ideas about ways to get out of the conflict, which results in the development of an agreement or unilateral actions of the parties, entailing their refusal to use jurisdictional methods of conflict settlement. All the above strategies, from rivalry (avoidance) to cooperation (compromise, adaptation), the plaintiff's waiver of the claim, and recognition of the claim by the defendant are inherent in alternative dispute resolution in civil proceedings in Ukraine, in particular during the conclusion of agreements in civil proceedings and the settlement of civil disputes with the participation of a judge.

\section{MATERIALS AND METHODS}

This study prioritised certain methods of scientific cognition. Firstly, to determine the legal nature, essence, criteria of correlation, and delimitation of alternative dispute resolution and judicial conciliation, the dialectical method of scientific cognition was used. It helped analyse the institution of amicable settlement in a broad (essential) understanding. As a result, the possibility of the wide application of the amicable agreement without the existence of a judicial process was stated. The dialectic and dichotomy of mediation in a broad understanding allowed us to define them as so-called out-of-court settlement agreements. After all, at the conclusion of an out-of-court settlement agreement, a civil dispute is still absent as such, and there is a substantive legal conflict between the persons. And only after a person appeals to the state, arbitration court, or international commercial arbitration, the legal conflict is transformed into a substantive claim as a subject of civil dispute, which in turn acquires such features depending on the nature of the dispute and the rules of civil jurisdiction (Frye, 2019). Such a conclusion was reached with the help of the Aristotelian method of scientific cognition. The system-structural method allowed to analyse and establish the distinction between the non-jurisdictional nature of the settlement of conflicts between persons through out-of-court settlement and judicial reconciliation.

Using the Aristotelian method of scientific cognition and the method of synthesis, the unique legal nature of 
the amicable agreement was identified, and it was concluded that it is incorrect to equate the conclusion of an amicable agreement with such conciliation procedures as negotiation, conciliation, and mediation. The method of synthesis allowed us to conclude that the identification of these categories in some way negates the essence of other alternative dispute resolution, which can also be reached by amicable settlement as a consensual compromise result of taking into account the interests of the parties. Modelling methods, Aristotelian and prognostic methods were used to investigate the long-term actions of various persons that precede the conclusion of an amicable agreement: negotiations, actual mediation, coordination of the interests of all stakeholders. Such actions may have legal significance in case of further litigation. Also, the prognostic and modelling method allowed us to study the positional strategies of conciliation procedures, which are most clearly manifested in negotiations: from rivalry (competition, positional bidding) as a manifestation of force style, to avoidance strategy - conscious withdrawal from interaction and confrontation. Such strategies in negotiations usually occur at the beginning: one party acts from the standpoint of a forced scenario, and the other party engages in avoidance. However, with a positive settlement of the legal conflict, the proposed strategies can be transformed into a strategy of cooperation and adaptation in the form of unilateral concessions on each part, and end in a consensual compromise in which the parties, although in fact do not fully satisfy their interests, however, reach an agreement on fundamental interests in a particular legal relationship.

\section{RESULTS AND DISCUSSION}

\section{Types of Alternative Dispute Resolution in Civil Procedural Law}

Sungatullina et al. (2019) identify five main groups of rules governing legal relations in the field of alternative dispute resolution: 1) extra-judicial (nonjurisdictional) use of alternative dispute resolution; 2) pre-trial (pre-jurisdictional) use of alternative dispute resolution; 3) judicial (jurisdictional) application of alternative dispute resolution; 4) assistance to the competent state bodies in the application of alternative methods of dispute resolution; 5) control over the use of alternative dispute resolution, which can be both state (for example, judicial) and public (for example, self-regulatory organisations, unions of specialists in the field of alternative dispute resolution). Next, the study will illustrate the most common types of alternative ways of settling and resolving civil disputes. Each alternative way of resolving civil disputes by its legal nature can become an independent subject of separate thesis research, including the development of theoretical system concepts. Therefore, within this study's framework, these alternative ways will be considered from the angle of belonging to the types of conciliation procedures. All over the world, mediation constitutes one of the most promising options for organising conciliation procedures, in connection with which the concept of conciliation procedures is often reduced exclusively to this method of dispute resolution.

\section{Mediation and Intermediation}

Interest in mediation is conditioned by the fact that its emergence was the result of the use of advanced scientific achievements in the field of conflict resolution (Ogrenchuk, 2016). Mediation is based on a scientifically sound and practically tested method of conducting principled (cooperative, integrative) negotiations (Zdrok, 2013). T. Frye (2019) defines intermediation (mediation) as a method of resolving a conflict between the parties based on negotiations involving a neutral person (an intermediary) with the purpose of concluding a binding agreement on the disputed issue. The third party does not have the authority to make a decision. The scientist identifies two main forms of intermediary procedures engaged in by subjects depending on the stage of development of the dispute: 1) commercial intermediation, which is carried out by independent mediators before the parties to the dispute apply to the state judicial authorities; 2) intermediation within the state court proceedings as a kind of judicial law enforcement activity. L. Dvořáková and M. Nečasová (2019) defines mediation as a negotiation process carried out with the help of an independent party - a qualified mediator. S. Assanova et al. (2020), essentially identifying mediation and intermediation, interprets the latter as negotiations between the parties to the dispute with the participation and under the guidance of a neutral third party - the intermediary who has no right to make a binding decision for the parties. R. Sharma (2018) state a wide scope of intermediary functions and identify specific groups based on the law of common law countries, in particular, American doctrine:

- scrivener mediation: a procedure with the superficial intervention of the intermediary in the course of the conflict, in which the intermediary 
only presides over the negotiations of the parties;

- $\quad$ supervisory mediation: the intermediary actively works on the subjective side of the conflict; on the negative perceptions of the other side, which are strengthened by the parties; over their intentions and behaviour, overcomes hostility between the parties;

- shuttle mediation or structured mediation: the intermediary mainly works with the parties separately, filtering information and controlling the interaction of the parties;

- power mediation or muscle mediation: the intermediary can put pressure on the party. Usually, this is the settlement of a dispute by a person to whom both parties to the dispute are subordinate or dependent (for example, a joint manager, the chief in labour disputes).

The authors of this study proceed from the synonymy of the studied concepts because even the Civil Procedural Code of Ukraine, initially establishing the circle of persons who cannot be questioned as witnesses of persons who "by law are obliged to keep secret the information entrusted to them in connection with the provision of intermediation (mediation) services..." (Paragraph 2 Part 1 of Article 70), legislatively consolidates intermediation and mediation as in some way synonymous phenomena. A key distinguishing feature of mediation among other types of alternative dispute resolution is that the mediation function becomes professional and reaches the level of technology. Thus, negotiations between the parties are conducted under the guidance of a person who has undergone special training, involves a specially structured procedure, and the purposeful use of effective communication techniques. As an innovative technology, mediation should be actively used by the state in organising conciliation procedures to ensure the current level of their quality, but excessive enthusiasm for new technology and attempts to abandon all other conciliation procedures in favour of the exclusive application of this new one is a negative trend and does not promote alternative dispute resolution (Zdrok, 2013). Since Ukraine still has not adopted a special law that would regulate the mediation procedure, it should be noted that there is an unformalised national legal framework for mediation in Ukraine; however, integrated provision of mediation is anticipated (Ogrenchuk, 2016).
The only ground for the emergence of mediation relations is an agreement. In general, there are two stages of contractual relations that contribute to the emergence of mediation relations: the agreement between the parties to the dispute on their consent to mediate and the agreement on mediation. An agreement between the parties to a dispute on their consent to conduct mediation may exist both in the form of a separate agreement and in the form of a mediation clause to the principal agreement, the performance of which is disputed. The specific feature of this type of agreement lies in the possibility of unilateral renunciation, which is a manifestation of one of the basic principles of mediation - the principle of voluntariness. The mediation agreement is concluded between the parties to the dispute and the mediator and regulates issues related to the organisation and conduct of the mediation procedure. By its legal nature, it is a contract for the provision of services (Ogrenchuk, 2016).

\section{Arbitration Court and International Commercial Arbitration}

These procedures have many common features, in particular: the presence of stages of consideration and resolution of private law disputes, payment for the procedure, the end of the dispute resolution procedure by a decision. Therefore, it is expedient to consider these types of conciliation procedures together. The resolution of a civil dispute takes place with the participation of an independent, neutral group of persons or a person (arbitrator/arbiter or group of arbitrators), who consider and resolve a civil dispute independently, making a decision binding on the parties. This constitutes the main difference from mediation, where the mediator, albeit is a specially authorised person, does not make/adopt the decision, and the final document is another relevant agreement, which was examined above. In addition, another specific feature of arbitration and international commercial arbitration, given their purpose, is primarily the nature of adversarial rather than conciliation proceedings, although in their contradict the requirements of la (Assanova et al., 2020). In the case of successful arbitration and international commercial arbitration, the parties have no desire to apply to state courts in the future. In some way, arbitration competes with the judicial form of protection of civil rights and interests of individuals and legal entities. It is often considered the best way to resolve disputes. As arbitration proceedings are conducted under a simplified procedure, courts usually do not set strict 
requirements for the form. There are no appeals and cassation appeals in arbitration proceedings, and court proceedings are not delayed for many years. Qualitatively performed arbitration serves to relieve the state courts. Conversely, the poor resolution of the dispute and the decision of the arbitral tribunal, as well as the low legal culture of the participants in the arbitration proceedings, only increases the burden on state courts and does not help protect the violated rights of individuals and legal entities (Bobryk, 2014).

In general, there are two types of international commercial arbitration: permanent (institutional) and ad hoc arbitration (isolated or administered arbitration). Institutional arbitrations are established for an indefinite period of time, mainly at chambers of commerce, exchanges, associations, and operate in accordance with their regulations. Ad hoc arbitration is established to consider a particular case and ceases to exist at the end of such consideration (Zadorozhna, 2012; Krupchan, 2012). Institutional arbitration has some acknowledged advantages over ad hoc arbitration: a permanent arbitral tribunal provides the parties with an accessible, impartial instance that resolves cases quickly and without significant expense, is made up of colleagues who deserve the most trust, can gain experience, and guaranteed stable judicial practice (Inchakova and Kazachenok, 2018). Jurisdictions of arbitration are also divided into general and special (Zadorozhna, 2012). Arbitrations of general jurisdiction include international commercial arbitration courts at chambers of commerce (industry) of different states, which consider the general category of cases (Inchakova and Kazachenok, 2018). The Law of Ukraine "On arbitration courts" (2004) imperatively establishes the impossibility of extending the effect of this law to international commercial arbitration. That is, the key difference between these alternative ways of resolving civil disputes is the nature of the disputed relationship (Part 3 of Article 1). This refers to the impossibility of arbitration of disputes in the implementation of foreign trade and other types of international economic relations. Disputes are subordinate to the ICAC in the presence of a foreign element in the process of carrying out foreign trade activities and other types of international economic cooperation (Frye, 2019).

\section{Settlement}

The settlement is the most important part of the conciliation mechanism for resolving disputes as to the most optimal tool for resolving contradictions and conflicts for participants in private law and society in general. This is due to the fact that the terms of the settlement of the dispute in the settlement agreement are set by the parties themselves during the negotiations, and it helps to maintain a stable favourable relationship between them. The specifics of the settlement agreement as a legal institution is its accessory nature; it is always based on certain legal relations of the parties, is their continuation, and cannot be concluded in the absence of the parties (Diependaele et al., 2019). The current legislation enshrines the possibility of concluding the trial by settlement agreement of the parties and stipulates the obligation of judges to assist the parties in conciliation. However, approaches to the forms of organisation of such assistance and means aimed at encouraging the parties to take part in conciliation procedures are diverse and, in part are completely opposite (Zdrok, 2013). If, in previous years, the issue of the implementation of settlement agreements was perhaps the most problematic, then with the adoption of the new edition of the procedural codes, more legal regulation, and features of its implementation were allocated to this issue.

Statutory consolidation of the settlement agreement in Articles 207, 208 of the Civil Procedural Code of Ukraine is carried out at the appropriate level and suggests that the settlement agreement, although related to conciliation procedures directly and organically, in itself is rather their result, a specific means of legal registration and consolidation of the termination of the dispute reached during such procedures. The formal side of a single conciliation mechanism for resolving a conflict (dispute) is concluded in a settlement agreement, while its informal side lies in negotiations, mediation, or other procedure for finding a mutually acceptable solution. It is the institution of a settlement agreement that is usually found in the sphere of legal regulation in various legal systems, but the methods of achieving it are largely unregulated, the procedure for their implementation in the interests of the flexibility of such procedures remains at the discretion of the parties, as long as these methods do not contradict the requirements of the law (Assanova et al., 202). Thus, in the literal meaning, a settlement agreement is a joint statement or other document of the contractual type, which states all the rights and obligations of the parties to the subject matter of the dispute and other claims. The conclusion of a court settlement agreement occurs after the initiation of a judicial process (arbitration) by a 
party to the dispute; such an agreement must be approved by the court. Article 207 of the Civil Procedural Code of Ukraine allows the parties to go beyond the subject matter of the dispute with a clause of non-infringement of the rights or legally protected interests of third parties.

\section{Negotiations}

Negotiations serve to maintain a stable favourable relationship between the parties to the relationship, as well as act as an organic component of the beginning, action, and termination of any civil relations. This is generally an objectively natural component of public relations, protected by law and part of the daily work of a lawyer. In general, negotiations are an indicator of the ethics and democracy of a developed civil society when used as a primary stage in resolving any social conflicts. As for the affiliation of negotiations to conciliation procedures, they are the most popular and most common way to resolve civil disputes from the standpoint of considering the interests of the parties. Negotiations can be a standalone way and a leading component of other alternative ways of resolving the dispute, which also emphasises their universal nature. At the same time, unlike the settlement agreement, the universal nature of negotiations lies in the process of various factual actions, meetings, and negotiations, correspondence, etc., resulting in a certain action that will have legal significance: the implementation of the relationship in kind, change or termination, adoption of a settlement agreement, novation, etc. whether the person's right to judicial protection is exercised in the form of an appeal to the court with a corresponding statement of claim.

Thus, according to Article 11 of the Civil Code of Ukraine, the most common basis for the emergence of civil relations is an agreement. Despite all the variety of named and unnamed contractual constructions in civil law, usually, when concluding the principal contract, the parties establish a specific reservation on the settlement of conflicts and disputes through negotiations. The essence of negotiations lies in the direct dialogue between the parties (direct negotiations) and/or their representatives (intermediation, mediation), pursuing the goal of mutual agreement, the acceptability of the outcome of the conflict. For example, G.O. Ogrenchuk (2016) gives preference to direct negotiations, noting that in the system of alternative dispute resolution negotiations are those that do not involve a third party in resolving disputes, while mediation is one of the latter (together with the arbitral tribunal) and substantiates the belonging of negotiations to the necessary components of mediation, and describes the establishment of a constructive negotiation process as one of the tasks of mediation. Negotiations may also end with the consent of the other party to perform the legal relationship in connection with which the material and legal conflict arose, in kind, to change it or to terminate it unilaterally. A party can make such a decision by analysing its legal position in a possible future civil case and an insufficiently reasoned line of defence, based on the available factual circumstances. Mediation negotiations of various types form, in fact, a separate type of conciliation procedures.

\section{Settlement of a Civil Dispute with the Participation of a Judge}

This type of alternative settlement of civil disputes is the latest in the civil procedure of Ukraine and national doctrine, which is found in the scientific literature under the name "judicial mediation". This innovation of civil procedural law can be recognised as an alternative way of resolving a civil dispute because, in fact, the initiation of litigation in civil jurisdiction has already taken place: "Settlement of disputes with the participation of a judge is carried out by agreement of the parties before the start of the consideration of the case on the merits" (Law of Ukraine..., 2017) - Part 1 of Article 201 of the Civil Procedural Code of Ukraine. The mentioned procedural institution is realised when the legal conflict was transformed into a dispute by filing a claim with the competent court. In addition to that, judicial conciliation also embodies all the necessary features of a conciliation procedure: a civil dispute is not resolved by a court, but is regulated by a specific competent highly qualified intermediary, as well as a court represented by a judge, however, not during the legal proceedings conducted by such a judge, but upon the performance of certain formal and informal actions by the judge, which are aimed at settling a civil dispute within the framework of the law. Such actions lie in creating all the necessary conditions for the settlement of a civil dispute with the achievement of mutual consent of the parties, as a result of which an appropriate resolution is adopted to terminate judicial consideration of a civil dispute. In addition, depending on the basis of such mutual consent of the parties, the judge may issue a decision recognising the claim as a defendant or the plaintiff's waiver of the claim.

Modern procedural law in most European countries allows for the possibility of combining conventional 
justice and procedures and alternative dispute resolution. The experience of European countries indicates that mediation can be used not only to resolve a dispute that has already been referred to a competent court for review but is also useful in many disputes that are sensitive to future relationships and carry reputational risks (for example, labour, family, and corporate disputes), and can be used at any stage of dispute resolution (Protiven, 2018). In particular, T. Kyselova (2017) and L.Zh. Romanadze (2017), conceptually exploring the principles and procedures of integration of mediation (in its various manifestations) into the judicial system of Ukraine, form the following types of judicial mediation: voluntary mediation with a mediating judge and dispute resolution procedure with a judge. The latter, in their opinion, with which the authors of this study agree, cannot be considered mediation as such because it is rather a kind of special court procedure. As the authors note, this procedure was tested within the framework of the UkrainianCanadian project on judicial reform and was called "negotiations on pre-trial dispute resolution with the help of a judge". In the initial version, the model allowed the judge who participated in settlement of the dispute between the parties to make a decision on the case (Rules of procedure..., 2018). Kyselova and Romanadze also state that in a modified format, this model was included in the Draft Law on Amendments to the Civil, Commercial, and Administrative Procedural Codes (Kyselova, 2017).

The study by T. Kyselova (2017) and L.Zh. Romanadze (2017) was conducted during the existence of the said draft law, but the content of the rules in the draft and adopted versions of the codes is similar; therefore, for this study, it appears prudent to present the opinion of these researchers regarding the advantages and risks (difficulties of implementation) of the model of dispute settlement with the participation of a judge, which was proposed by the legislator. Advantages of the model: judges, according to this model, have the highest level of interest in mediation, as it will save them the time they spend on court hearings; the parties do not incur additional costs, their cost is covered by court fees; the parties do not bear the risks associated with the statute of limitations due to the fact that the procedure is conducted after filing a claim with the court. Complexities of the model: not all judges may be interested or have the ability to resolve disputes; there are risks of manipulation of unrecorded private meetings between the parties and the judge and risks of abuse of the procedure by the parties in order to replace the judge in the absence of grounds for the recusal of the judge. The current civil procedural legislation of Ukraine establishes certain temporal reservations about the existence of this institution in the initiated civil proceedings:

1) the opportunity to settle the dispute with the participation of a judge before the decision on the merits (Part 1 of Article 201 of the Civil Procedural Code of Ukraine);

2) implementation of the settlement procedure within a reasonable time, but not more than thirty days from the date of the decision to carry it out. The mentioned time limits of the possibility of this type of conciliation procedure distinguish it among other methods and procedures of peaceful settlement of disputes used in civil proceedings, particularly the institution of the settlement agreement, which can be implemented at any stage of the trial.

Notably, the procedure for settling a civil dispute with the participation of a judge established in the Civil Procedural Code of Ukraine does not make provision for the involvement of a specially trained mediating judge (such as voluntary mediation with the participation of a mediating judge). Settlement of the dispute is performed by a judge who considers the case, regarding which this judge, in case of consent of both parties personally (and not their representatives), makes a decision and terminates the proceedings (Article 202 of the Civil Procedural Code of Ukraine). Thus, the settlement of a case with the participation of a judge is not, in essence, a manifestation of mediation in its usual form (considering its broad and narrow understanding). Since the settlement of civil disputes involving a judge and mediation have many common features, in particular, in terms of involving a professional participant, under whose direction the mediation procedure is conducted, some types of conflicts and their attributes, which, as the scientific doctrine indicates, can be subject to mediation in essence, are as follows: 1) the conflict arose in a social group consisting of two subjects or formed on the principle of a dyad, in connection with which its settlement is not available, in particular, by voting (Smolyaninova et al., 2020); 2) this refers to long-term, important relations for the parties, in connection with which the dominant are not the legal claims of the partners in the conflict related to the past, but their future interests and the possibility of maintaining normal relations in the future; 3 ) the situation is strongly 
influenced by the emotional side of the conflict; 4) the parties prefer to maintain confidentiality; 5) the legal dispute covers only part of the problem, while the task is to work out a general solution; 6 ) there is a factually or legally complex case that cannot be resolved in the interests of both parties (or will be unsatisfactorily resolved) with the help of law due to its binary "yes no", and therefore the court decision in this case will most likely be appealed (Esanova, 2020; Smolyaninova et al., 2020; Lazarev, 2011).

\section{CONCLUSIONS}

Judicial conciliation combines the features of involving a specialised mediator who negotiates the mediation procedure. However, the judge does not agree with the parties but assists them in resolving the dispute by clarifying the grounds and subject matter of the dispute, explaining to the parties the subject of evidence in the case, and taking other actions aimed at a peaceful settlement of the dispute. The judge may also suggest to the parties a possible way of peaceful settlement of the dispute (Part 4 of Article 203 of the Civil Procedural Code of Ukraine). However, the judge is empowered to hold both general and closed meetings with each of the parties. When holding a closed meeting, the nature of the negotiations that the judge should actually conduct is theoretically traced. In such actions of the judge, who resolves the dispute, the signs of mediation can also be traced. However, as mentioned above, the mediator does not make any decisions personally, but only through professional negotiations and explaining the benefits of certain concessions to each party, facilitates independent acceptance of a certain agreement by the parties, which is formalised by an agreement or a settlement agreement, if the mediation took place in parallel with the litigation.

In contrast, the judge who settles a civil dispute, in the case of obtaining mutual consent of the parties during the proceedings, decides on the peaceful settlement of the dispute depending on the nature of the agreement and the decision reached by the parties. Such features are inherent in the arbitration court and the settlement of the dispute by arbitration - the presence of an authorised person to resolve the dispute. However, if in arbitration proceedings the judge (arbitrators) makes a decision independently, based on the positions of the parties (i.e., the review is described by elements of adversarial proceedings), the judge who settles the dispute in accordance with the provisions of Chapter 4 of the Civil Procedural Code of
Ukraine, only records in the procedural document - the decision (judicial act, which will be considered an executive document in the future) -the mutual consent of persons based on the positions of the parties, but not in a clearly defined legal plane of the civil dispute (statutory nature of the dispute), that is, the judge can consider the relevant compromises of the parties.

This study proved that alternative dispute resolution and judicial conciliation are closely interrelated and, depending on their type, can sometimes manifest as synonymous categories or institutions of law. However, there is no good reason to recognise conciliation procedures as a generic category for alternative ways of resolving a civil dispute, as both categories may arise: at the time of litigation, or during pre-trial proceedings (claims, negotiations, conciliation, etc.), in parallel with the emergence of litigation, as well as in general as a completely independent way of resolving and settling a legal conflict (dispute) without recourse to a competent state court through another quasijurisdictional body (arbitration) or without recourse to such a body whatsoever. A certain affinity of alternative dispute resolution and judicial conciliation allows formulating the definition of conciliation procedures in civil proceedings - legitimate ways of consensual settlement of legal conflicts (civil disputes) by legal entities, which arose between them based on reciprocal mutually acceptable conditions, based on public, social, economic or other interests with the possibility of involving other persons (whom the law allows involving) for this procedure.

The settlement of a civil dispute may be performed directly by the parties or with the involvement of third parties. The role of third parties is to help the parties better understand each other, to reach an agreement, to bring their positions closer, and in some cases also to offer options for the conditions under which a dispute can be settled. However, all decisions on the fate of the dispute in non-jurisdictional ways of overcoming legal conflicts are made by the parties themselves. The thirdparty (mediator, reconciler, etc.) does not investigate the evidence, does not establish the facts. Its key task is to establish and ensure mutual understanding between the parties and identify opportunities to resolve the problem on terms acceptable to all parties. Thus, negotiations contribute to the purpose of conciliation procedures and various ways of resolving civil disputes: to negotiate and promptly, free of charge or cheaper, resolve a substantive conflict within the framework of law, and not in strict compliance with the rules of law. For the latter, there is another way - 
appeal to the competent court in accordance with the rules of jurisdiction and competence.

\section{REFERENCES}

Arkhipkina, Anastasiya, Igor Arkhipkin, and Marianna Dyachuk. 2020. "New in the Legislation on Conciliation Procedures in Russia: Judicial Conciliation and Mediation". Journal of Siberian Federal University. Humanities and Social Sciences 13(2): 167-178. https://doi.org/10.17516/1997-1370-0548

Assanova, Saida. Serikkali Tynybekov, Arkhat Abikenov, Sarsengaly Aldashev, and Gulyiya Mukaldyeva. 2020. "Problem Aspects of Mediation Dispute Resolution". Rivista Di Studi Sulla Sostenibilita 2020(1): 215-233

Bobryk, Volodymyr. 2014. Unification and Differentiation of Procedures of Civil, Economic, and Administrative Proceedings. Kyiv: Research Institute of Private Law and Entrepreneurship named after F.G. Burchaka.

Chan, Peter. 2017. "An empirical analysis of judicial conciliation in China", pp 182-202. Mediation in Contemporary Chinese Civil Justice: A Proceduralist Diachronic Perspective. Leiden: Brill.

Constitution of Ukraine. 1996. (https://zakon.rada.gov.ua/laws/show/ 254\%D0\%BA/96-\%D0\%B2\%D1\%80\#Text).

Diependaele, Lisa, Fedri de Ville, and Sigrid Sterckx. 2019. "Assessing the Normative Legitimacy of Investment Arbitration: The EU's Investment Court System". New Political Economy 24(1): 37-61. https://doi.org/10.1080/13563467.2017.1417362

Draft Law of Ukraine "On mediation" No. 3504. 2020. (https://goo.su/3bUq).

Draft Law of Ukraine "On mediation" No. 10301/10301-1. 2012. (https://goo.su/3BUo).

Draft Law of Ukraine "On mediation" No. 2425a/2425a-1. 2013. (https://goo.su/3BuL).

Draft Law of Ukraine "On mediation" No. 2480/2480-1/3665/3665-1. 2015. (https://goo.su/3BUK).

Draft Law of Ukraine "On mediation" No. 7481. 2010. (https://goo.su/3BuR).

Draft Law of Ukraine "On mediation" No. 8137. 2011. (https://goo.su/3BuN).

Dvořáková, Lenka and Mirka Nečasová. 2019. "Mediation as a Method of Social Work or Unique Behavioral Pattern?" Socialni Prace 19(5): 70-86.

Esanova, Zamira. 2020. "Priority Aspects Application of the Institute of Mediation in Resolution of Disputes: National and Foreign Experience". International Journal of Advanced Science and Technology 29(5): 1785-1793.

European Commission for the Efficiency of Justice (CEPEJ) "Mediation development toolkit ensuring implementation of the CEPEJ guidelines on mediation". 2019. (https://rm.coe.int/mediation-development-toolkit-ensuringimplementation-of-the-cepej-gui/16808c3f52).

Frye, Timothy. 2019. "Contracting in the Shadow of the State: Private Arbitration Commissions in Russia", pp. 123-138. The Rule of Law and Economic Reform in Russia. London: Routledge. https://doi.org/10.4324/9780429495878-7

Galiakbarova, Guzal, and Sholpan Saimova. 2016. "Mediation of Labour Disputes in Kazakhstan in Comparative Context". Russian Law Journal 4(2): 96-111. https://doi.org/10.17589/2309-8678-2016-4-2-96-111

Goretsky, Oleh. 2016. "Conciliation Procedures in Civil Proceedings: Foreign Experience of Legal Regulation". (http://www.spilnota.net.ua/ru/article/id-1628/).

Inchakova, Agnessa, and Svetlana Kazachenok. 2018. "To principles in the jurisprudence of international commercial arbitration: $A$ comparative study of the London Court of International Arbitration and the International Commercial Arbitration Court at the Chamber of Commerce and Industry of the Russian Federation". Journal of Legal, Ethical and Regulatory Issues 21(3): 12-38.

Kalashnykova, Svetlana. 2011. Mediation in the Field of Civil Jurisdiction., Moscow: Infotropic Media.

Kosovsky, Leonid. 2016. Claim Proceedings in Civil Cases with a Foreign Element. Kyiv: FG Research Institute of Private Law and Entrepreneurship Burchak NAPrN of Ukraine.

Krupchan, Oleksandr. 2012. International Commercial Arbitration Court: Compliance Today. Kyiv: Research Institute of Private Law and Entrepreneurship of the National Academy of Pedagogical Sciences of Ukraine.

Kyselova, Tamara. 2017. Integration of Mediation into Ukrainian Court System. Kyiv: SSRN. https://doi.org/10.2139/ssrn.3054519

Law of Ukraine "On amendments to the Commercial Procedura Code of Ukraine, the Civil Procedure Code of Ukraine, the Code of Administrative Procedure of Ukraine and other Legislative Acts" No. 2147-VIII. 2017. (https://zakon.rada. gov.ua/laws/show/2147-19\#Text).

Law of Ukraine "On arbitration courts" No. 35. 2004 (https://zakon.rada.gov.ua/laws/show/1701-15\#Text).

Law of Ukraine "On the judiciary and the status of judges" No. 1402VIII. 2016. (https://zakon.rada.gov.ua/laws/show/140219\#Text).

Lazarev, Sergey. 2011. Fundamentals of Judicial Reconciliation. Moscow: Infotropik.

Moltmann-Willisch, Anne-Ruth. 2014. "Extra-Judicial and Judicial Mediation and Attempt of Settlement as A Prerequisite for Bringing A Dispute to Court". (https://goo.su/3bwm).

Ogrenchuk, Ganna. 2016. Legal Regulation of the Use of Mediation in Resolving Civil Disputes. Kyiv: National Academy of Internal Affairs.

Protiven, Oleksii. 2018. "Reconciliation of the Parties vs. Settlement of the Case: The New Role of the Court in Resolving Conflicts". Lawyer and Law 3: 1-7.

Romanadze, Luiza. 2017. "Dispute Resolution with the Participation of a Judge and Other Procedural Novelties: Impact on The Development of Mediation". (https://goo.su/3bu4).

Rules of procedure for conducting negotiations on pre-trial settlement of a dispute with the assistance of a judge. 2018. (https://adm.od.court.gov.ua/sud1570/gromadyanam/dosydo v/reglament)

Sakhnova, Tatyana. 2012. "The Procedurality of the Civil Process the Methodology of the Future". Bulletin of the Civil Process 1: 9-24.

Sharma, Rej. 2018. "Mediation Rules of the ARMO for State-To-State Disputes: Effective, Efficient and Practical". Asian Journal of WTO and International Health Law and Policy 13(1): 47-62.

Smolyaninova, Olga, Vera Korshunova, and Olga Andronnikova. 2020. "Formation of Mediation Competence of Participants in the Educational Space of the Krasnoyarsk Territory in the Siberian Federal University". Perspektivy Nauki i Obrazovania 47(5): 413-428. https://doi.org/10.32744/pse.2020.5.29

Sungatullina, Lilia, Robert Izmailov, and Andrey Mikhaylov. 2019 "Mediation as Alternative Dispute Resolution: Legal Analysis, Foreign Practice, and Perspectives in Russia". Humanities and Social Sciences Reviews 7(6): 826-829. https://doi.org/10.18510/hssr.2019.76124

Szymanski, Craig and Katerzyna Antolak-Szymanski. 2020. "The Role of Unions in American Labour Mediation". Lavoro e Diritto 34(1): 117-145 https://doi.org/10.31743/recl.4510

Thomas, Robert, Joe Tomlinson. 2017. "Mapping Current Issues in Administrative Justice: Austerity and the 'More Bureaucratic 
Rationality' Approach". Journal of Social Welfare and Family Law 39(3): 380-399.

https://doi.org/10.1080/09649069.2017.1363526

UNCITRAL Arbitration Rules. 1976. (http://zakon5.rada.gov.ua/ laws/show/995_059).

UNCITRAL model law on international commercial arbitration. 1985. (http://zakon0.rada.gov.ua/laws/show/995_879).
Zadorozhna, Svitlana. 2012. Commercial Dispute Resolution: Alternatives to Public Litigation. Kyiv: Research Institute of Private Law and Entrepreneurship of the National Academy of Legal Sciences of Ukraine.

Zdrok, Oksana. 2013. Conciliation Procedures in the Civil Process: a Modern Theoretical Concept. Minsk: Byiznesofset.

Received on 01-01-2021

DOI: https://doi.org/10.6000/1929-4409.2021.10.48

(C) 2021 Tykhanskyi et al.; Licensee Lifescience Global.

This is an open access article licensed under the terms of the Creative Commons Attribution Non-Commercial License (http://creativecommons.org/licenses/by-nc/3.0/) which permits unrestricted, non-commercial use, distribution and reproduction in any medium, provided the work is properly cited. 